\title{
Effects of Brix, processing techniques and storage temperature on the quality of carambola fruit cordial
}

\begin{abstract}
Two methods of processing carambola fruit cordial were compared using a cold method (CM) and a hot method (HM). Characteristics of the freshly prepared product were compared. Samples were later prepared at $35^{\circ}, 45^{\circ}$ and $55^{\circ}$ Brix concentrations and stored at $25{ }^{\circ} \mathrm{C}$ and $5{ }^{\circ} \mathrm{C}$. The responses measured during storage were changes in $\mathrm{pH}$, titratable acidity, ascorbic acid content, Brix, viscosity, colour, pulp sedimentation and sensory attributes of colour and taste. The $\mathrm{pH}$ remained stable during storage but did not show any correlation with titratable acidity, which fluctuated. The ascorbic acid content decreased. Temperature seemed to have an effect on Brix and viscosity values, colour and pulp sedimentation. The $35^{\circ}$ and $45^{\circ}$ Brix CM cordials stored at $5{ }^{\circ} \mathrm{C}$ were more acceptable in terms of colour and taste. $\mathrm{CM}$ did not seem to be a feasible technique for producing cordial from fresh fruit.
\end{abstract}

Keyword: Brix; Carambola fruit cordial; Storage temperature 